$E$
77
55

n
$\frac{n}{1}$
$\frac{\pi}{\Gamma}$
$\Gamma$ 


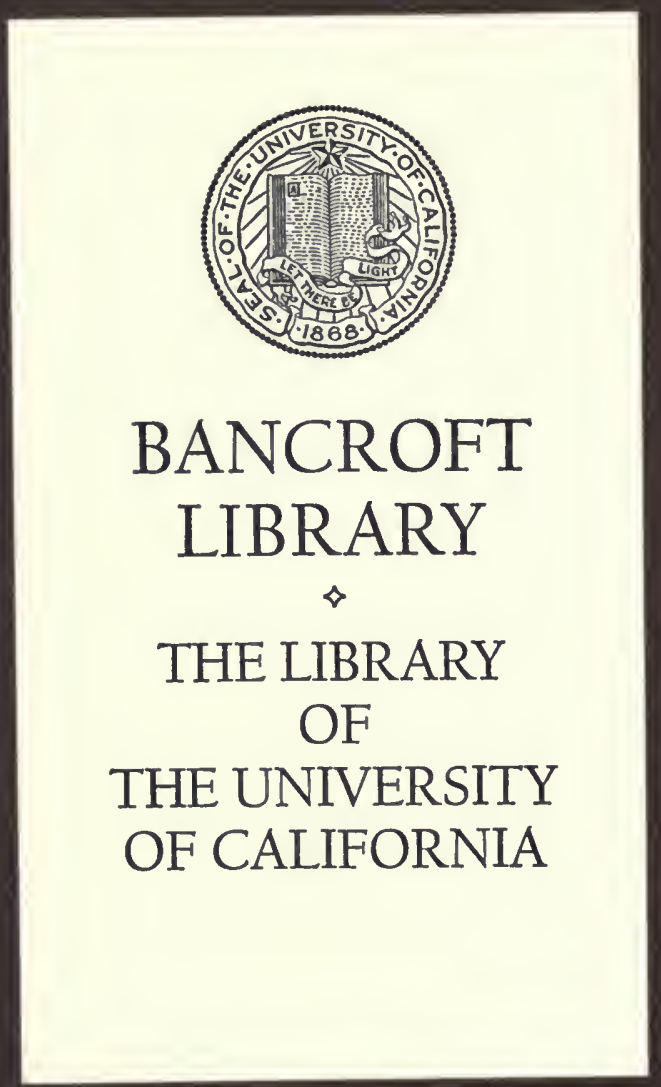


ABORIGINAL TOBACCOS

By WILLIAM ALBERT SETCHELL

Reprinted from Tue American Antirropologist, Vol. 23, No. 4, October-December, I92 T. 


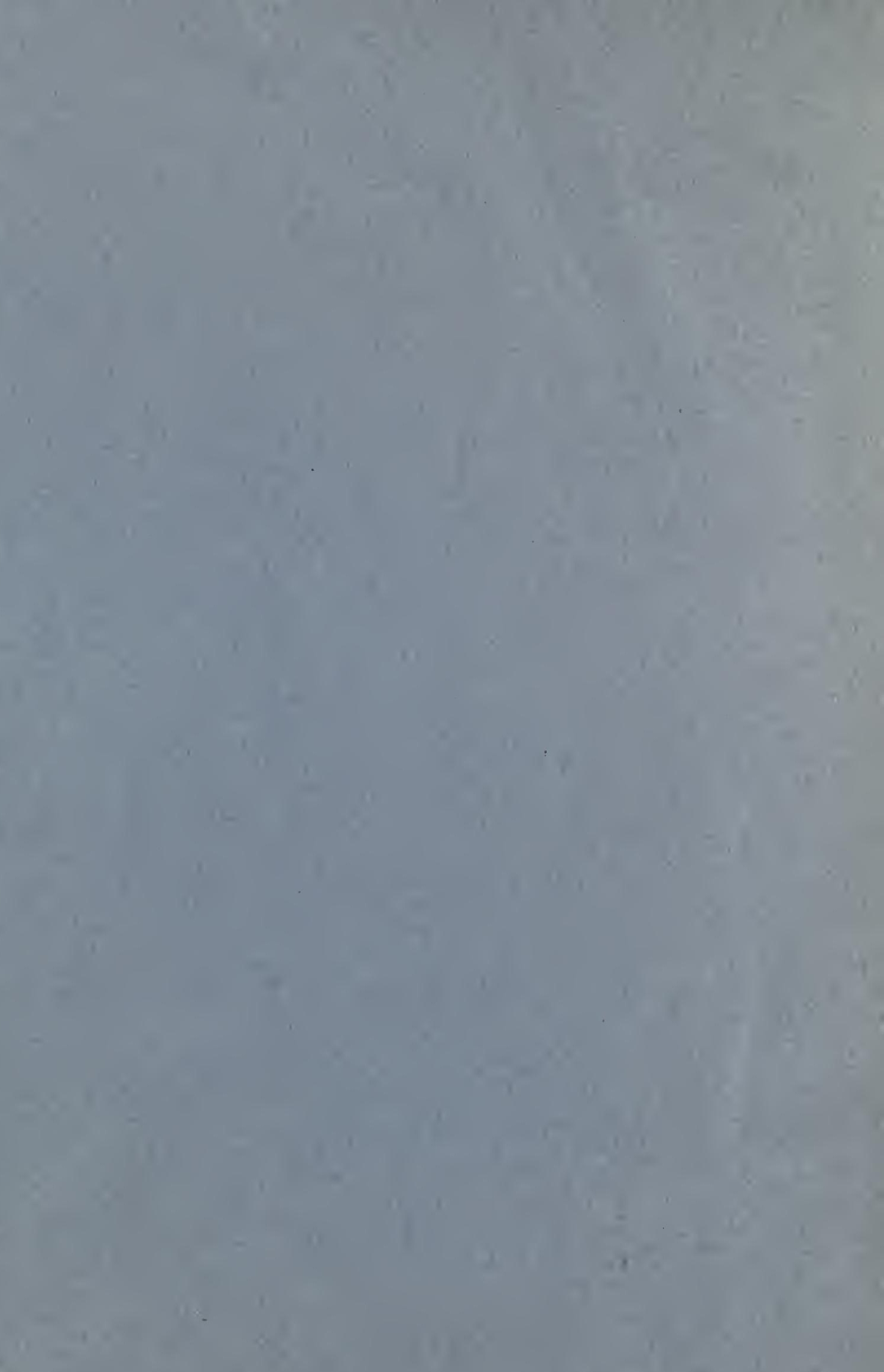





$$
\begin{aligned}
& E 77 \\
& S_{5}
\end{aligned}
$$


[Reprinted trom the American ANThropologist, Vol. 23 , No. 4, Oct.-Dec.. 1921.]

\title{
ABORIGINAL TOBACCOS
}

\section{By WILLIAM ALBERT SETCHELL}

\begin{abstract}
CCORDING to De Candolle in his Origin of Cultivated Plants, ${ }^{1}$ A somewhat over forty of the plants now generally cultivated came from the Americas, some of them having been introduced into Europe very soon after the discovery of the "new continent" by Columbus. This has been regarded as being true particularly of maize, potatoes, and tobacco. There have not been wanting claims as to other origins for many of these supposedly American cultivated plants and the tobaccos have frequently been under suspicion. The most careful investigations, however, have tended only to confirm the idea of the non-existence of any species of tobacco used for smoking, snuffing, or chewing outside the confines of the American continents. The latest writer to claim a non-American origin for tobacco, as well as certain other cultivated plants of supposedly American origin, is Leo Wiener. ${ }^{2}$ Professor Wiener devotes ninety pages of his book to a consideration of tobacco, chiefly from the point of view of its various names. His conclusions appear to be that the cultivated tobacco originated in Africa and was introduced thence into the Americas by Negro slaves imported by the Spaniards. The linguistic evidence brought forward by Professor Wiener seems to one unacquainted with the value of such evidence as to origins and migrations of peoples, plants, etc., to be far-fetched and

1 Origin of Cultivated Plants, in Internat. Sci. Series, vol. 48, New York, 1885 .

2 Africa and the Discovery of America, vol. I, Philadelphia, 1920.

26


often trivial. The discussion of this portion of Wiener's claim has been taken up by one well qualified to estimate its worth. ${ }^{1}$

The botanical evidence, however, has not been dealt with to any extent by Wiener, and, in fact, he does not seem at all aware that there is any complexity to this side of the question he attempts to settle so readily and so smugly. While we are by no means certain as to the exact sources of the two species of Nicotiana most commonly used for smoking, viz., Nicotiana Tabacum and N. rustica, all evidence in our possession is strongly against the assumption of a nonAmerican origin. It seems to the botanist that Nicotiana Tabacum, for example, is much more likely to have been carried from Brazil or the West Indies, where its culture was early widespread, if not aboriginal, to Africa, by the very agents who procured the Negro slaves for American use. In doing so, it seems very likely that the Brazilian or other American names may thus have been transferred early to Africa along with the plants to which they belonged, and have become firmly and extensively incorporated into African native languages. However this may or may not be, the strongest botanical evidence for the American origin of the tobaccos, as used by man, is the existence of a large number of species of Nicotiana, undoubtedly native to the Cordilleran ranges, extending from the State of Washington in the United States of North America to the central portions of Chile in South America. The only species of Nicotiana which are undoubtedly extra-American are two, viz., $N$. suaveolens and $N$. fragrans, natives of the Australian region, closely related to certain Chilean species, and never used for smoking or similar purposes before the advent of the white man to the countries where they are known to occur.

Of the somewhere in the neighborhood of seventy species of Nicotiana generally recognized, there are to be found in North America, either growing wild or in aboriginal cultivation, some fourteen species. Of these fourteen North American species, I have evidence of the use of nine species or varieties by different tribes of American Indians at the present time. At present they are used

1 Cf. R. B. Dixon, American Anthropologist, vol. 22, no. 2, April-June, 1920, especially pp. 179-181, and "Words for Tobacco in American Indian Languages," ibid., vol. 23, no. 1, pp. 19-49. 
only, or at least chiefly, for ceremonial purposes, their use for smoking generally having been superseded by the trade-tobacco early introduced by the white traders. It is to the close association of tobacco with the religious and social observances of the various tribes of North American Indians that we owe the continuation of the use, and particularly of the cultivation, of aboriginal tobaccos and the opportunity of obtaining first-hand information as to the species employed as well as to the ceremonies connected with their use. For somewhat over fifteen years I have been collecting information on the subject of the species employed and have importuned every anthropologist who was luckless enough to come into my circle of acquaintances to assist in obtaining seed of any possible species of Nicotiana still found to be in aboriginal use. The result has exceeded my original expectations by far, and a number of species which I had imagined to be beyond further proof than mere mention of their employment by one tribe or another have been found still in use and either cultivated or collected wild. Of these, seed has been procured in practically all cases, and I have been able to grow it in the botanical garden at the University of California and assure myself as to the identity.

The use of narcotics is found to be general wherever they are readily available and it is remarkable how quickly and how widely the use of a narcotic will spread when once introduced. This has been particularly the case with tobacco after the discovery of America, as Tiedemann ${ }^{1}$ has so convincingly shown. The extent of the use of the narcotics, tobacco and coca, in the Americas previous to 1492 is well delineated by Wissler. ${ }^{2}$ Wissler's chart distinguishes between the areas where tobacco was chewed and those where it was smoked, and it even distinguishes between the areas where the tubular or elbow pipes were smoked and those where cigars or cigarettes were employed. This chart indicates that tobacco was used over the whole of both Americas with the exception of the extreme northern portions of North Ámerica and the extreme southern portions of South America. The tribes of North American Indians who were fortunate enough to dwell in a region provided with a native species

1 Geschichte des Tabaks, Frankfurt a M., $18_{54}$.

2 The American Indian, fig. 8, New York, I9i7. 
of Nicotiana seem to have learned to use it and to have paid little or no attention to its cultivation. Some such tribes, however, did burn over small areas to make the wild tobacco grow more abundantly or more luxuriantly. The tribes of North American Indians, living in areas destitute of a native species of Nicotiana, either cultivated some species or obtained their supply from other tribes who had a supply, cultivated or wild. The relation of the different species of North American tobacco to the various trade routes of the Indians has not as yet been investigated, but some suggestions as to these relations may become apparent as I proceed with the present discussion. When tobacco was cultivated, its planting, at least, was usually attended with more or less elaborate ceremonies.

The species of Nicotiana which is best and most widely known is Nicotiana Tabacum L. It is pink-flowered and is the only species belonging to its section of the genus. The variation within the species, however, is so very considerable that at least five subspecies may be segregated, and, superficially at least, these seem distinct enough to be considered as species. The subspecies may each be divided and subdivided again and again into a very large number of varieties and subvarieties, so that, in general, Nicotiana Tabacum has all the ear-marks of an old and widely cultivated plant. The cultivation of this species, in its various forms, is almost exclusive at present for the tobacco trade of all nations. It was the aboriginal tobacco of the West Indies, of the greater part of Mexico, of the states of Central America, of the United States of Colombia, of Venezuela, of the Guianas, and of Brazil. The Brazilian name of this species is said to have been "petun," and this name was very generally used for tobacco in the accounts of it in the sixteenth century. Wiener ${ }^{1}$ thinks that this word is a corruption of the Portuguese "betume," meaning a pasty substance. It seems strange that this derivation of the name was not known, if true, to any of the writers on tobacco of the sixteenth and seventeenth centuries. The Mexican name for Nicotiana Tabacum, "piecelt," was also early widespread.

The origin, as well as the original sources, of Nicotiana Tabacum

1 Loc. cit., p. 135 . 
is uncertain, since it is not known in the wild condition in any of the countries where it is under cultivation. It seems probable that it may have originated in the interior of Brazil and possibly somewhere on the lower eastern slopes of the Andes. It is very evidently a tropical species and in the tropics often becomes spontaneous, escaping from cultivation and persisting in favorable localities. Some varieties are semi-hardy in regions of little frost, but frostless and humid areas are evidently similar to its ancestral home. Edward Palmer found it in Indian cultivation in southern Arizona under the name of "Yaqui Tobacco." 1 This "Yaqui Tobacco" is referred by Gray to the var. undulata Sendtner. North of Mexico, however, Nicotiana Tabacum was practically unknown in aboriginal use.

The yellow-flowered tobacco, Nicotiana rustica L., was the second species of tobacco to attract the notice of Europeans and for some time almost monopolized attention. This was the first species of tobacco to be cultivated in the Colony of Virginia. It was fairly soon supplanted there, however, by a variety of Nicotiana Tabacum called "Orinoco," introduced, it is said, by Sir Walter Raleigh, or through his recommendation. Nicotiana rustica is still the homegrown species of the peasants of Central Europe and still furnishes the Syrian "Tombac" for the water-pipes of western Asia. It is a much more hardy species than is Nicotiana Tabacum and has been credited with being a native of the Old World. There seems to be no exact evidence, however, that this is so, and, although it has not been found in undoubted wild condition, the general supposition is that it probably originated in Mexico. It seems fairly certain that it is American and probably Cordilleran like all its near relatives of the Rustica section of the genus Nicotiana. Like Nicotiana Tabacum, $N$. rustica was described and figured in pre-Linnean herbals, especially in certain of those of the sixteenth century, where it was designated as the lesser or female tobacco, while $N$. Tabacum was called the greater or male tobacco.

Nicotiana rustica seems to have been cultivated and smoked by all of the Indian tribes of North America east of the Mississippi River and by most of those immediately to the west of it. The west-

1 Gray, Synoptical Flora of North America, vol. 2, pt. I, New York, 1878, p. $24 \mathrm{I}$. 
ern boundary of its aboriginal cultivation or use is, naturally, difficult to determine with exactness, but is probably along the line of the eastern boundary of the "Plains Area" as outlined by Wissler." The use of this species, then, may be supposed to have extended over the "Eastern Woodland Area" and the "Southeastern Area" of the social groups of North American Indians as classified according to their cultures. The evidence on which this supposition is based is scanty, but reasonably convincing. In the first place, we know that smoking was general over these culture areas and was held of importance as a ceremony. In the second place, Strachey, about i6ro, ${ }^{2}$ speaks definitely of the flower of the tobacco of the Virginian Indians as having a yellow color and otherwise as conforming to the description of Nicotiana rustica. It is interesting to note here that the Indian name for the Virginia tobacco was "Uppowoc," or, as Strachey wrote it, "Apooke." In the third place, the Onondaga Indians, center nation, fre-keepers, tobacco nation, and holders of the responsibility of general referendum of the Five Nations or Iroquois, still cultivate Nicotiana rustica as the "Sacred Tobacco" of their confederacy. I have been able to grow plants from Onondaga seed kindly furnished by Chief Cornplanter through Arthur C. Parker. W. M. Beauchamp ${ }^{3}$ mentions Nicotiana rustica as the species called "O-yen-kwa-hon-we," and I have seen specimens of the Onondaga plant provided by him in the Herbarium at the New York Botanical Garden. The Iroquois tradition of the origin of the tobacco plant is related by Arthur C. Parker. ${ }^{4}$ As stated by Esquire Johnson, an old Seneca chief, to Mrs. Asher Wright, the missionary, the squash grew from the earth directly over Earth-Mother's navel, the beans from that above her feet, and the tobacco-plant from that above her head. "Thus," he added, "it soothes the mind and sobers thought." In the fourth place, tobacco seed from the Winnebago Indians of Minnesota, furnished by Dr. Melvin R. Gilmore, yielded Nicotiana

1 Loc. cit., p. 207.

2 Strachey, William, The Historie of Travaile into Virginia Brittania, Hakluyt Society, London, pp. 121, 122, 1849.

3 Onondaga Indian Names for Plants, Bull. Torrey Botan. Club, vol. 16, pp. 54,55 .

4 Indian Uses of Maize and other Food Plants, Bull. No. 114, New York State Museum, 1910, p. 37 . 
rustica, on being grown. In the fifth place, and finally in the evidence, there occur spontaneous plants of Nicotiana rustica in various parts of these general areas, which seem to be remnants of earlier Indian cultivation. Possibly some of these which have been collected and recorded may have been ballast weeds or escapes from cultivation more recent than that of the Indians, but some of them seem fairly certainly to be relics of aboriginal culture. Such possible remnants of Indian cultivation are credited to Connecticut, New York, Wisconsin, Illinois, Minnesota, and Texas, in other words indicating an aboriginal cultivation of Nicotiana rustica extending well over the general areas to which I have assigned it. These facts, together with the general plausibility of the supposition, have led me to map out the areas of aboriginal culture for this species as I have indicated above.

The third section of the genus Nicotiana is called the Petunioidessection whose corollas are typically salverform and whose color is white, although often tinged with green, red, or purple. About twelve species or well-marked varieties of this section occur within the confines of North America or the adjacent islands, but only seven of them are at all definitely known to me as having been used by the Indians. There is a most interesting group of five species and varieties centering about Nicotiana Bigelovii (Torr.) Watson and one very widespread species Nicotiana attenuata Torr. The five species of this section of the genus which are not as yet known to have been in use by the Indians are the following: Nicotiana acuminata var. parviflora Comes. ?, in central California; $N$. Clevelandii Gray, in southwestern California, possibly used by the Santa Barbara and other tribes of coast Indians; $N$. repanda Willd, in southwestern Texas and adjacent partions of Mexico; $N$. plumbaginifolia Viv., in northeastern Mexico and crossing the Rio Grande into Texas; and $N$. Stocktoni Brandegee, on Guadalupe Island off the coast of Lower California.

The Nicotiana Bigelovii-group consists of three very well marked varieties of $N$. Bigelovii (Torr.) Watson, $N$. quadrivalvis Pursh, and $N$. multivalvis Landl. There is such a close resemblance in so many details of habit and structure that it certainly seems probable that the five distinct genetic entities of the Bigelovii-group must have.origi- 
nated from one and the same stock, possibly through mutation, but probably also complicated by more or less hybridization. Their distribution in nature and under aboriginal cultivation reënforces this assumption with strong arguments. The three varieties of Nicotiana Bigclovii are found native in three separate portions of California, N. multivalvis was cultivated by the Indians in Oregon, Idaho, and Montana, while $N$. quadrivalvis was similarly cultivated in North Dakota. The distribution of this group runs from southern California north through the entire state of California and well into Oregon, possibly also entering the southeastern corner of the state of Washington. From Oregon, it bends eastward up along the tributaries of the Columbia River, across Idaho and the continental divide, and descends the Missouri River into Montana and North Dakota. With these ideas as to the group and its distribution, the way is made ready for a consideration of its various members.

Torrey was the first to call attention to Nicotiana Bigclovii which he named $N$. plumbaginifolia? var. Bigclovii. This was as early as I857. In $187 \mathrm{I}$, Watson raised the variety to a species and published a more complete description, as well as a good figure of it. The type specimens came from the Sierran foothills in central California and are low spreading plants, with short internodes, ascending branches, large and conspicuous white flowers, and prominent glandular pubescence turning brownish, or rusty, with age. S. A. Barrett tound it in the general type region in use among the Miwok Indians and was kind enough to obtain seed for me. I have grown it in the pure line for many years and find that it retains its distinctive varietal characteristics from generation to generation. This plant, the taxonomic type of Nicotiana Bigelovii, occupies an area in the very center of California which is definitely limited and also separated from the areas occupied by the other varieties of the species.

The plant which has usually passed under the name of Nicotiana Bigclovii, however, is the tall erect variety found in abundance in the dry washes of stream-beds to the north of San Francisco Bay, from Sonoma, Mendocino, and Humboldt Counties eastward to Shasta and possibly also other counties of California. This variety, which as yet has no distinctive name, may reach a height of as much as six 
feet, has long erect branches with elongated internodes, and with large flowers which are more separated than in the plants of the taxonomic type. In common with the type of the species, this tall and erect variety has a decided tendency toward a three-celled ovary and such are to be found in most well-developed plants although in a small percentage of the total number of capsules matured. Chestnut $^{1}$ states that this variety is used for smoking and also for chewing by all the Indian tribes of Mendocino County, California. Thanks to P. E. Goddard ${ }^{2}$ and S. A. Barrett, I have perfectly reliable evidence that it is still used by the Hupa and the Pomo. The Hupa, at least, knew it both wild and cultivated, ${ }^{3}$ but the Pomo seem to have used only the wild plant. As to how far the use of this variety extended into Oregon I am uncertain, but I have the opinion that, towards its northern limits and beyond them, attempts were made to cultivate it, as certainly was the case among the Hupa. Northern California represents the limit of the spontaneous distribution of any coastal species of Nicotiana and in Oregon we find that the cultivated tobacco of certain Indian tribes was a nearly related species, or possibly.derived variety, of $N$. Bigelovii, viz., N. multivalvis Lindl.

There can be little doubt that it was some form of the Bigeloviigroup of the genus Nicotiana which was used by the Indians whom Drake encountered in I 579, when he landed on the coast of California, somewhere in the vicinity of Drake's Bay. Wiener ${ }^{4}$ remarks on Drake's account as follows: "That tabaco, frrst mentioned in Hispaniola, should have found its way so far to the northwest, in addition to the rest of the continent, is a prima facie proof that the distribution of tobacco follows from its first appearance under Arabic influence, from Guinea to all countries where Spanish, Portuguese, and French sailors navigated via Guinea or after having taken part in Guinea expeditions." The extreme improbability of Nicotiana Bigclovii having originated in Guinea and having been brought thence

1 Plants used by the Indians of Mendocino County, California, Contr. U.S. National Herb., vol. 7 , no. 3, pp. 386, $387,1902$.

2 Life and Culture of the Hupa, in Univ. Calif. Pubs., Aner. Arch. and Eth., vol. I, no. I, p. 37, 1903.

3 Goddard, loc. cit.

4 Loc. cit., p. $14 \mathrm{~J}$. 
to the State of California, the only place where it has ever been known, and through any human agency, takes away the effectiveness of this "prima facic proof" and yields another strong probability that the tobacco of Hispaniola may have been carried from Hispaniola to Guinea rather than that any species of tobacco may have been brought from Guinea to Hispaniola or. any other portion of the American Continent.

The third variety of Nicotiana Bigelovii, the var. Wallacei Gray, is found in a limited area in southern California and distinctly separated, in its distribution, from either, or both, of the other varieties of the species. Var. Wallacei is a plant of medium height, erect, and much more slender than either of the two varieties of central and of northern California. It has a smaller flower with more slender tube and I have never seen a three-celled ovary among several thousand examined, all the ovaries, and ripe capsules, having been found to be two-celled. While it is very probable that this variety may have been used by the Indian tribes of the region where it occurs, I have been unable to obtain any direct evidence that such was the case. Its relations with Nicotiana Clevelandii Gray, both botanically and as to aboriginal use, are still very uncertain.

When Lewis and Clark visited the Mandan villages in North Dakota in I804, ${ }^{1}$ they found the inhabitants smoking a kind of tobacco never seen previously by white men. They obtained specimens and seed for their collections as well as data for their report. The specimens brought back by them served as the type of the Nicotiana quadrivalvis $\mathrm{Pursh}^{2}$ and are now preserved among the collections of the Academy of Natural Sciences of Philadelphia. The seed, or some of it at least, was distributed so that it was the source of the plants grown in various botanical gardens in Europe and its descendants are still to be found in some such institutions. A few years ago, through the courtesy of the Anthropological Section of the American Museum of Natural History of New York City, I was enabled to obtain from George F. Will of Bismarck, North Dakota, and from Melvin Ran-

1 Cf. Thwaites, Original Journals of the Lewis and Clark Expedition, 1804-1806, vol. I, pp. 183, I86, 187, 1904; vol. 6, pp. I42, 149-151, I58, 1905, New York.

2 Flora Americae Septentrionalis, vol. I, p. 141, 1814. 
dolph Gilmore of Lincoln, Nebraska, seed of this species which was still being cultivated by a Hidatsa Indian. I have grown the descendants of the plants from this seed and in the pure line for several generations and find that it still comes absolutely true to type as described by Lewis and Clark and as represented by the Lewis and Clark specimens. The plants very closely resemble those of the type of Nicotiana Bigelovii, but the flowers are neither quite so large nor so graceful. The chief difference from any of the varieties of $N$. Bigelovii, however, is to be found in the ovary. This is constantly four-celled in N. quadrivalvis, while in N. Bigelovii, it is preponderatingly two-celled, although three celled examples are frequent in the type and in the northern variety. Nicotiana quadrivalvis is not only the tobacco of the Mandan, but of the Arikara and the Hidatsa Indians as well. How they obtained it is not known, but it is not known outside of cultivation. This latter fact, taken in connection with the close resemblance to Nicotiana Bigelovii, the only essential difference being the increase in the number of carpels as shown by the four-celled ovary, makes it appear reasonably certain that $N$. quadrivalvis is only a derivative from some form of $N$. Bigelovii. It may possibly have arisen by a single mutation or it may be a hybrid derivative from a cross between $N$. Bigelovii and $N$. multivalvis. I have obtained forms very close to $N$. quadrivalvis as descendants of such a cross and such forms have appeared in the botanical garden of the University of California as the result of a probably spontaneous cross between the two species mentioned. It is of decided interest to find a Bigclovii-derivative so far from the Bigelovii home and this interest is increased by the fact that $N$. quadrivalvis is connected in distribution with the Californian area by the area in which $N$. multivalvis, itself seemingly a Bigclovii-derivative, is found under aboriginal cultivation.

The Hidatsa tobacco, which is fairly certainly Nicotiana quadrivalvis, has been the subject of study by Gilbert L. Wilson. ${ }^{1} \mathrm{He}$ says that the Hidatsa cultivate tobacco, but does not mention the species. It is not used by the young men because it prevents running by

I Agriculture of the Hidatsa Indians, an Indian Interpretation, Univ. of Minnesota Studies in the Social Sciences, no. 9, Minneapolis, 1917, pp. 121-127. 
causing shortness of breath. It is not planted near corn because tobacco has a strong smell that affects corn. In harvesting, the blossoms are picked first, the white parts (corollas) being thrown away, and the stems and leaves are picked last. - Both blossoms and stems are treated with buffalo-fat before being stored. The Hidatsa name for their tobacco, according to Lowie, ${ }^{1}$ is ópe.

Melvin Randolph Gilmore, ${ }^{2}$ in treating of the uses of plants by the Missouri River Indians, writes as if they all used Nicotiana quadrivalvis, ${ }^{3}$ although he mentions specifically that his definite knowledge was of the Hidatsa tobacco only. He states that $N$. quadrivalvis was cultivated by all the tribes of Nebraska, ${ }^{4}$ but was lost as soon as they came into contact with Europeans and so completely that not even the oldest Omaha had ever seen it in cultivation. It seems fully as probable that the Nebraska tribes, being nomads, may not have cultivated tobacco, but probably obtained it by trade. In this case it seems just as likely that they may have obtained Nicotiana rustica from Indians of the Eastern Woodland Area or N. attcmuata from those of the Plains Area, as to have received $N$. quadrivalvis from any one of the three tribes of village Indians of North Dakota.

Nicotiana multivalvis Lindl., the fifth and last member of the Bigelovii-group to be considered, bears a striking resemblance to the type of $N$. Bigelovii and also to N. quadrivalvis in habit, leaves, and shape-as well as color-of the flowers. The corolla, however, is usually more than five-lobed, varying to as many as twelve or more lobes. The ovary is the characteristic feature of the species. It is composed of two circles of cells, one within the other as in the case of the ovary of the navel-orange. The capsule of $N$. multivalvis bears fertile seeds in all, or at least in most, of its cells. Such a form of ovary as this is evidently monstrous, at least from the point of view of the normal ovary of Nicotiana, and may be supposed to have been derived from a form such as the type of $N$. Bigclovii by a rela-

1 The Tobacco Society of the Crow Indians, Anthrop. Papers, Amer. Mus. Nat. Hist., vol. 21, pt. 2, 1919.

2 Uses of Plants by the Indians of the Missouri River Region, 33rd Ann. Rep. Bur. Amer. Ethnology (for 1911-12), pp. 43-154, 1919.

3 Loc. cit., p. 59.

4 Loc. cit., p. 113 . 
tively simple mutation. An additional argument'as to the possible derivation of this species from some simpler form is the fact that it has not been found outside of cultivation.

Nicotiana multivalvis was discovered by David Douglas ${ }^{1}$ in August, 1825 . The first specimen he saw of it was in the hands of an Indian at the great falls of the Columbia River, but, although he offered two ounces of manufactured tobacco, an enormous remuneration, the Indian would not part with it. The Indians planted it away from the villages so that it could not be pulled before maturity. They burned a dead tree or stump in the open wood and strewed the ashes over the ground to be planted. Later on, Douglas found one of the little plantations and helped himself to specimens. Soon after, however, he met the owner who appeared much displeased on seeing the plants under Douglas's arm. A present of an ounce of European tobacco appeased him and the present of an additional ounce induced him to talk of the Indian tobacco and to answer questions concerning it. Douglas learned from the Indian that he put wood ashes over the ground because it was supposed that the ashes make the tobacco plants to grow very large. He also learned that this species of tobacco grew plentifully in the country of the Snake Indians, who may have brought it from the headwaters of the Missouri River which they annually visited, and have distributed it from this region and in both directions east and west of the Rocky Mountains. This suggestion of the Indian probably represents a portion of the truth as regards the travels of this species, but the general trend must have been rather from the coast to the eastward and into the interior, if the botanical probabilities are duly considered.

Through the kindness of Dr. Robert H. Lowie, of the American Museum of Natural History, I have been able to make certain that the tobacco which is of so much ceremonial importance among the Crow Indians is Nicotiana multivalvis. I have examined photographs of the tobacco gardens of the Crows, in which the plants showed their characters remarkably well, and also a pressed specimen of an entire plant concerning whose identity there can be no doubt.

1 Journal Kept by David Douglas, etc., I.ondon, 1914, pp. 59, 14I (sub. $N$. pulverulenta Pursh). 
Dr. Lowie ${ }^{1}$ has since published his paper on the subject and brought forward much detail concerning the planting and ceremonial use of this species. In his preface, Dr. Lowie says that the Tobacco Society loomed large in the tribal life of the Crow, its ceremonial activities probably ranking next to the Sun Dance. The Crows insist that their tobacco is different from that of the Hidatsa (Nicotiana quadrivalvis) and botanically this idea is correct. In connection with the query as to whence the Crow, and the Hidatsa as well, may have obtained their particular types of tobacco, Dr. Lowie, in addition to the botanical evidence, calls attention to the fact that in the languages of several of the tribes using the Bigelovii-group of tobaccos, the root of the word for tobacco is opp or $u p$ and that the Diegueños, the Shasta, the Takelma, the Crow, and the Hidatsa agree in this, while the tribes using.other species of tobacco apply terms from different roots. This linguistic evidence is of decided interest and importance, especially when taken in connection with the close botanical relationship of the species and varieties concerned.

We have seen that the Indians of the Eastern Woodland Culture Area and of the Southeastern Culture Area made use of cultivated Nicotiana rustica which probably came to them through the southwestern corner of Texas from Mexico. We may now see that the Indians of the greater portions of the Plains Area, the Southwestern Area, and even of the North Pacific Coast Area used an entirely different species, viz., Nicotiana attenuata Torrey. The tremendous extent of that portion of North America over which this species furnished the tobacco of the aboriginal tribes is divided into a northern and a southern section, as a glance at the accompanying map will show, by the intrusion of two members of the Bigelovii-group, viz., $N$. quadrivalvis and $N$. multivalvis. Nicotiana attenuata is found growing wild over the Southwestern Area and over the southern and middle portions of the Plains Area, at least to the westward, but was cultivated over the northern portion of the Plains Area and in the North Pacific Coast Area where it does not occur spontaneously. The condition in the easternmost portion of the Plains Area is not as yet clear to me.

\footnotetext{
1 Loc. cit.
} 
The type specimen of Nicotiana attenuata came from the Washoe country in Nevada and I have reliable testimony that it is still used by the Washoe Indians, especially by the older men. To the south, it is used by the Coahuilla Indians of southeastern California, ${ }^{1}$ and Leslie Spier has also kindly communicated to me that the Southern Diegueños about Campo, California, use this species, which they call "Coyote Tobacco," and infrequently cultivate it near house sites. It grows rapidly and high wherever the ground has been newly burned over. "Coyote Tobacco" is used by these Indians to cure colds. It is also used in the south by the Zuñi tribes, ${ }^{2}$ whence I have received seed through Prof. A. L. Kroeber and have raised plants, and by the Tewa Indians. ${ }^{3}$ It was used by the Utes, although not named by Chamberlain, ${ }^{4}$ and by the Gosiutes. ${ }^{5}$ Dr. Lowie has submitted to me some samples of the tobacco raised by the northern Blackfoot ${ }^{6}$ which seems, although fragmentary and much broken, to show the characteristic hairs of this species. I have received from Mr. James Teit of Spences Bridge, B. C. (through the kind offices of Dr. C. F. Newcombe of Victoria), seed of the tobacco formerly cultivated by the Thompson River Indians of that vicinity and have demonstrated that the plants grown from it are true Nicotiana attenuata. C. F. Newcombe has informed me that he has strong evidence that this species was also cultivated by the Indians of the Queen Charlotte Islands and used for chewing. The evidence for the extent of the aboriginal use of $N$. attenuata seems to be convincing for the area as mapped and as outlined above.

Nicotiana attenuata has something of the appearance of a slender N. Bigelovii, but its flowers are smaller and less distinctly salverform,

\footnotetext{
1 Barrows, The Ethnobotany of the Coahuilla Indians of Southern California, Univ. of Chicago, p. 74, 1900.

2 Stevenson, Ethnobotany of the Zuñi Indians, 3oth Ann. Rep., Bur. Amer. Ethnology, p. 86, 1915 .

3 Robbins, Harrington, and Freire-Marreco, Botany of the Tewa Indians, Bull. 55, Bur. Amer. Ethnology, pp. 103-107, 1916.

4 Chamberlain, Some Plant Names of the Ute Indians, Amer. Anthrop., n. S., vol. 11, 1909.

5 Ibid., Ethnobotany of the Gosiute Indians, Mem. Amer. Anthrop. Assoc., vol. 2 , pt. 5 , p. 345,1911 .

6 Lowie, loc. cit., p. II2.
} 
the lower leaves more distinctly petioled, while the glandular hairs often have a swollen, bladdery base which, in collapse, gives a blistery appearance. This appearance is of the greatest service in identifying fragments, particularly of the calyx parts. The plant itself is tall, erect, and often slender, although very robust plants are found in favorable localities.

One of the least satisfactorily known species of Nicotiana in North America is $N$. Clevelandii Gray. I know of this species only through the dried specimens in the different herbaria in this country. The specimens referred to this species even by Gray himself vary so considerably that I feel much doubt as to the exact nature of the specific characters. I have attempted to obtain plants and seeds from students who might be in a position to collect them, but without success. $N$. Clevelandii seems to have some characters similar to those considered peculiar to $N$. attenuata and other characters similar to those of N. Bigelovii var. Wallacei. Some specimens referred to $N$. Clevelandii have more the general appearance of one of the two species just mentioned, while others are very much more like the other of the two. One suggestion which seems probable is that these puzzling plants are hybrid derivatives of the two species which they resemble. So far as may be determined, $N$. Clevelandii is confined to the coastward side of southern California, extending from Santa Barbara to San Diego. The relation to aboriginal use or culture of this species is as unsettled as its botanical status. Rothrock ${ }^{1}$ states that he found $N$. Clevelandii only in association with shell heaps in the neighborhood of Santa Barbara, California, and, on account of the tobacco pipes found in the same heaps, suggests that this may be the species used by the tribes of Indians who made the pipes. Possibly, also, this may be the tobacco mentioned by Sparkman ${ }^{2}$ as having been formerly used by the Luiseño Indians of southern California and called in their language "pavivut."

There is a very interesting species, of striking appearance, Nicotiana trigonophylla, in the southwestern United States, ranging from

1 Botany, in Report U. S. Geog. Surveys West of the Iooth Meridian in charge of First Lieut. George M. Wheeler, vol. vi, p. 48,1878 .

2 The Culture of the Luiseño Indians, Univ. Calif. Pub., Amer. Archaeol. and Ethnol., vol. 8, p. 229. 1908. 
southeastern California to the western borders of Texas. Its aspect is very different from that of any other species of the genus in North America. It occurs in the lower portion of the territory occupied by Nicotiana attenuata where the latter species is the one usually employed for smoking. There is, however, a specimen in the U. S. National Herbarium (No. I3478), collected in Arizona by Edward Palmer in 1885 , which has the note " used by the Yuma Indians." I am very much indebted to Leslie Spier of the University of Washington for the information that this species (identified by Paul Standley of the U. S. National Herbarium) is used by the Havasupai Indians of Cataract Canyon in Arizona, a branch of the Yuman stock. The Havasupai distinguish two sorts of this tobacco which look alike, but which they say smoke differently. The Havasupai cut down a mesquite tree, burn it on the unbroken soil, and scatter the tobacco seed over the dead ashes.

The remaining four species of Nicotiana found native in North America, or in the islands immediately adjacent to it, viz., $N$. repanda Willd., N. nudicaulis Watson, N. plumbaginifolia Viv., and N. Stocktoni Brandegee, are not, so far as I have been able to ascertain, suspected of being associated with aboriginal use, although some of them seem as well adapted to smoking, at least, as some of those which are widely used.

University of California,

Berkeley, Calif. 


\section{EXPLANATION OF THE PLATE}

The map used to indicate the areas of use of the different species of Nicotiana in North America, is obtained from the Department of Anthropology of the American Museum of Natural History of New York City and is the same as that given by Dr. Clark Wissler in The American Indian (New York, 19r7, fig. I03). The lines delimiting the different Nicotiana areas follow more or less closely those used to mark off the various "Culture Areas" from one another (cf. Wissler, loc. cit., fig. 67), but with some differences. Within the different Nicotiana areas, the larger number within a single circle indicates the general species used, presumably throughout the area, while the smaller number within a circle indicates a tribe definitely known to have used it. The numbers in double circles placed without the borders of the land, but with arrows drawn to indicate the regions to which they belong, indicate, with the exception of No. 10, species not as yet known to have been in aboriginal use. The following is a list of the species, each with its appropriate number:

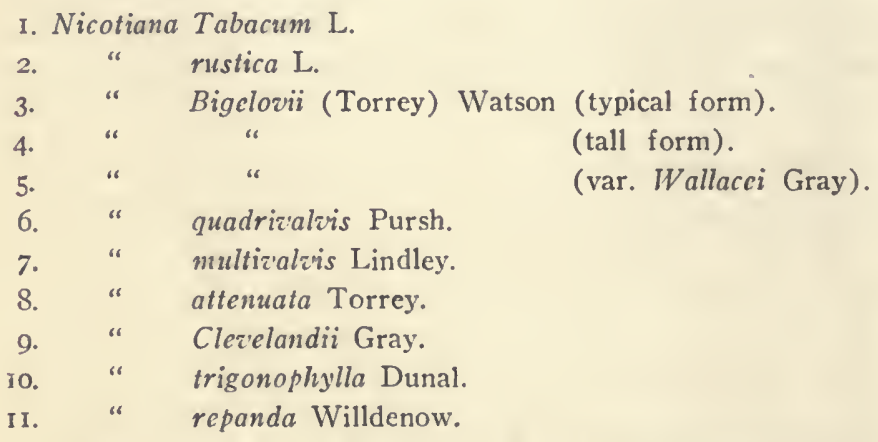

I am indebted to Mr. Charles E. Davis of Edgewood, R. I., for the preparation of this plate. 


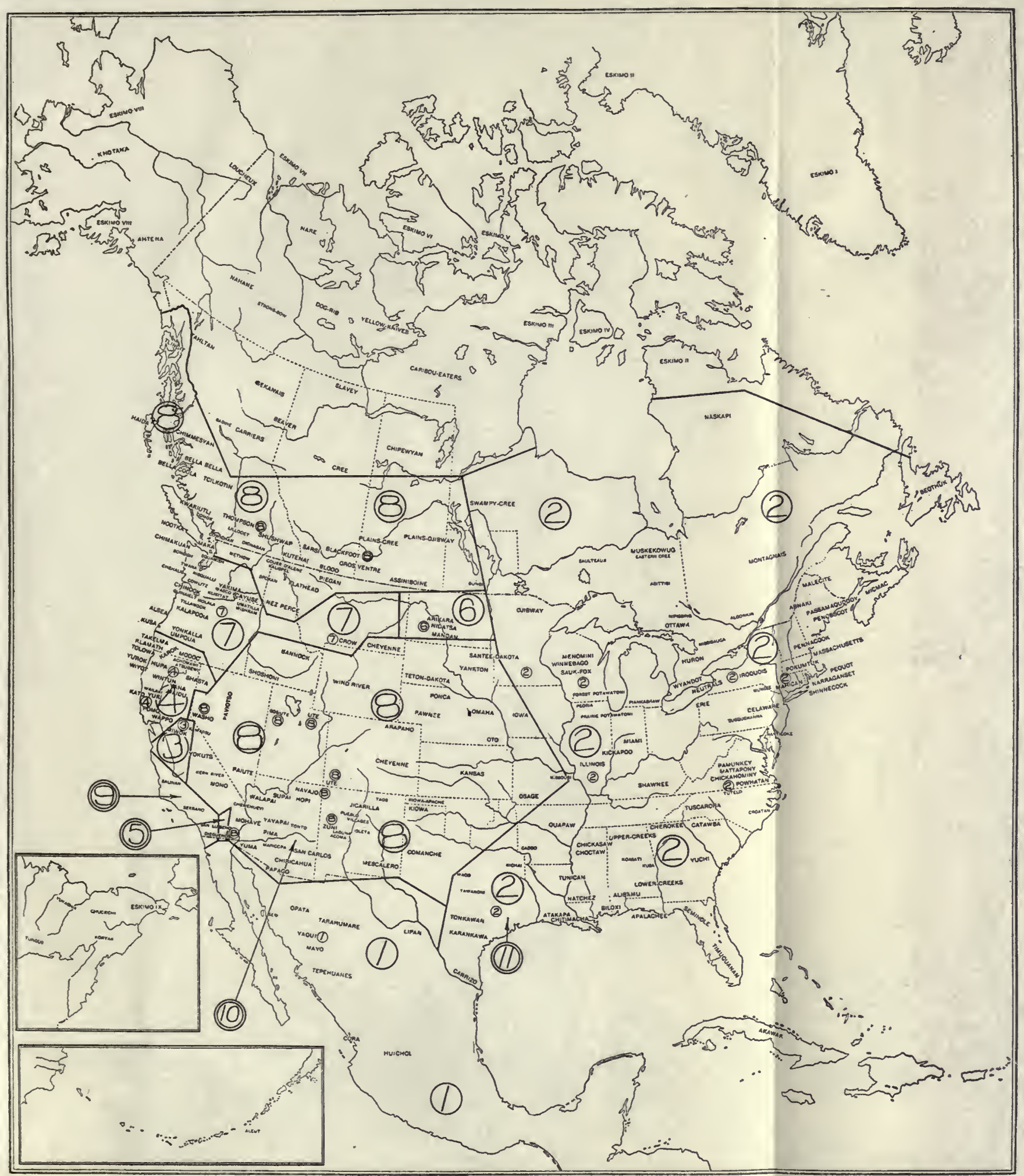




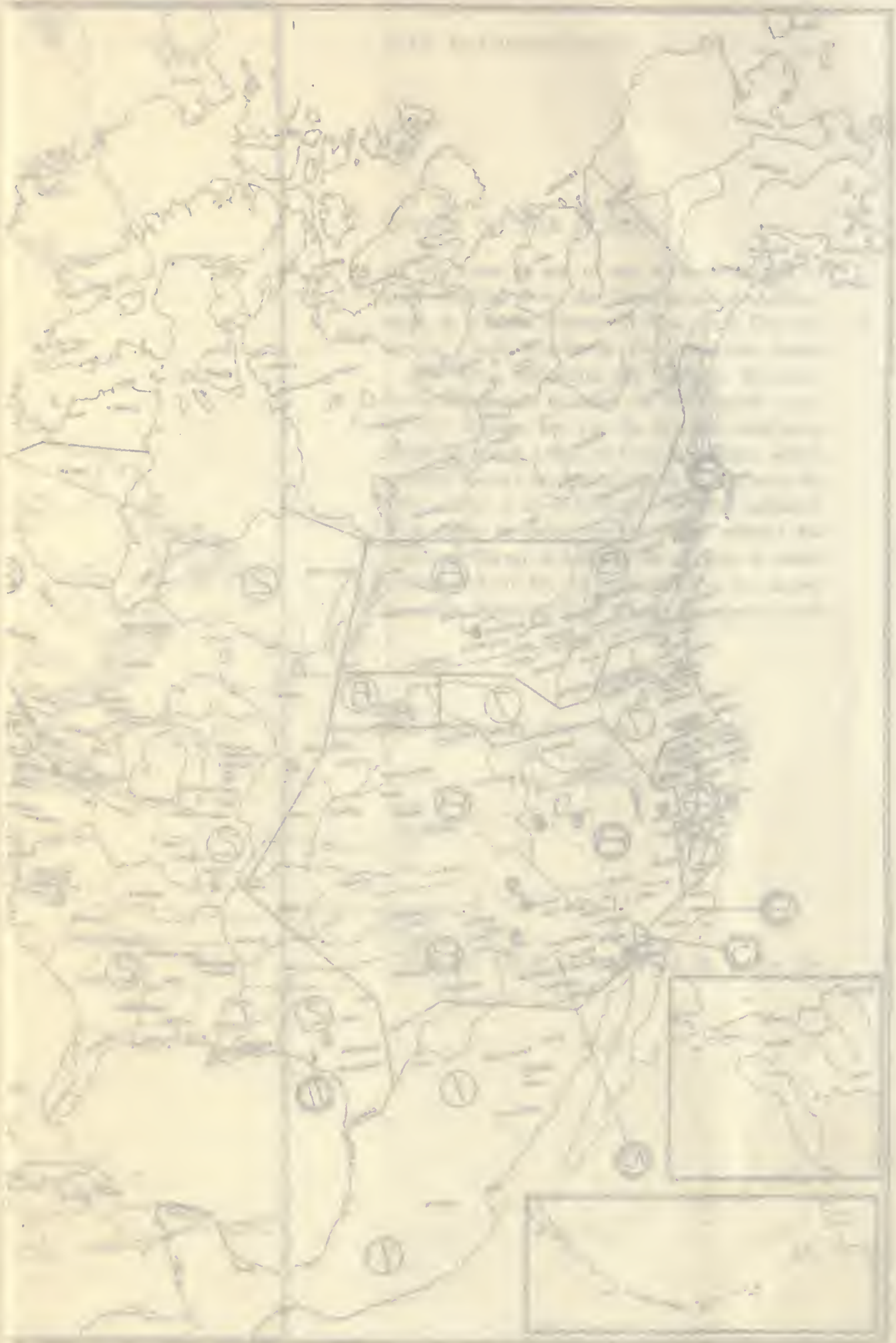





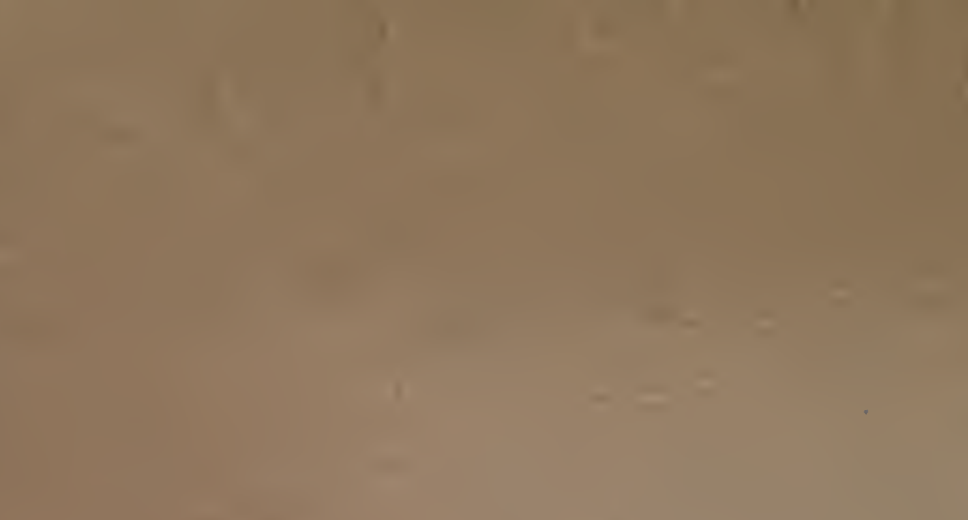

$=-x$

$+$
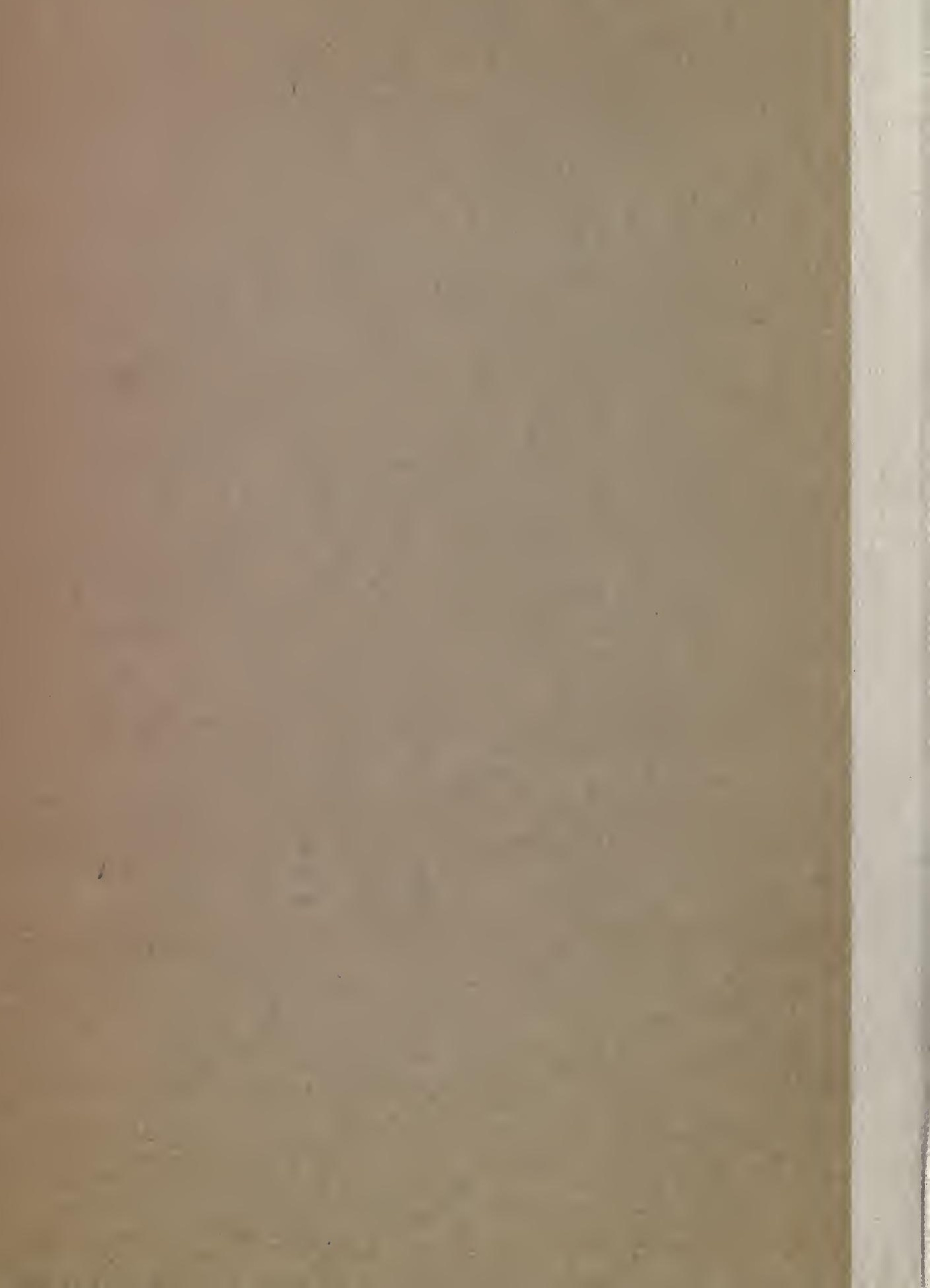